IVANA MANCE

\title{
TOWARDS THE THEORY OF THE NAÏVE ART - GRGO GAMULIN AND THE UNDERSTANDING OF MODERNISM
}

Grgo Gamulin (1910-1997), art historian, critic and author, was one of the central figures not only of Croatian art history in socialist Yugoslavia, but of its culture and public social life as well. While still a student at the University of Zagreb, he began to gravitate towards left-wing politics, publishing his first art critiques, in which he advocated for socially engaged art. Being a member of the Communist Party, public action became almost impossible between 1934 and 1941, while his war years were spent in Ustasha concentration camps. After the war, he began his public and university career as the head of the Ministry of Education's Department for Culture in Croatia's postwar government, and from 1947 he was employed at the Faculty of Humanities and Social Sciences of the University of Zagreb, where he took over the organisation of art history classes. Until 1971, when he was forced to retire for being a prominent member of the Croatian Spring movement, Gamulin taught classes in art history of the Early Modern Period and the Modern Age, remaining active as a scientist, art critic and author even after retirement. After gaining a PhD on the attribution methods in visual arts (1951), his scientific work was primarily dedicated to the painting of late-Gothic period up to the $19^{\text {th }}$ century, modernist painting and sculpture, and the issues of contemporary urbanism. In all these areas, Gamulin cultivated theoretically sound and methodologically consistent thought, writing fundamental studies and syntheses. Continuously present as an art critic and an interested witness to the art of the $20^{\text {th }}$ century, Grgo Gamulin was one of the main interpreters of modernism and modernist artistic phenomena in the context of Yugoslav socialism, which he both criticised and defended polemically, in accordance with his convictions, but also as part of his wide, outstandingly informed interest and human sensibility. The published works and manuscript legacy of Grgo Gamulin still represents one of the numerically largest corpora of Croatian art history. 


\section{GAMULIN VS. MODERNISM}

For a relatively long time, Gamulin's position on modernism would remain marked by the ideological fracture caused by the relatively short episode of the implementation of socialist realism in Yugoslavia. ${ }^{1}$ Although art historians generally agree that this cultural paradigm never really took hold at the level of artistic production in Yugoslavia, in the period between 1945 and 1949 - the year of the East-West bloc divide when Yugoslavia was left out of the Warsaw Pact - the artistic scene was institutionally constituted according to the Soviet totalitarian model, and the discourse of art criticism adopted the fundamental doctrines of socialist realism. ${ }^{2}$ Here it should be noted that the discussions on the understanding of socially engaged art, primarily literature, have been ongoing in Croatia and Yugoslavia since the interwar period, following the dynamics of constituting that paradigm in the Soviet Union from afar. ${ }^{3}$ For the pre-war development of visual arts in Croatia in this context, the decisive occurrence was the text that Miroslav Krleža ${ }^{4}$ published as a foreword to the map of drawings by Krsto Hegedušić, ${ }^{5}$ leader of the left-leaning, but also

${ }^{1}$ Gamulin's texts that investigate the concept of socialist realism were written between 1946 and 1954.

${ }^{2}$ Lj. Kolešnik, Izmedu Istoka i Zapada. Hrvatska umjetnost i likovna kritika 50-ih godina, Zagreb 2006, pp. 29-32; A. Šeparović, "U znaku totalitarizma," in: 150 godina Hrvatskog društva likovnih umjetnika. Umjetnost i institucija, ed. I. Kraševac, Zagreb 2018, pp. 173-200.

${ }^{3}$ Debates between left-wing intellectuals in Croatian historiography are usually described by the term "conflict on the left." According to S. Lasić, the beginning of the conflict can be traced to the year 1928, which was defining for the political life of the Kingdom of Yugoslavia (the assassination of the Croatian politician S. Radić, establishment of the $6^{\text {th }}$ January Dictatorship), but also in the field of artistic creativity (disagreements between left-oriented writers on the line of social literature/surrealism). Lasic places the end of the conflict in 1952, the year of the III Congress of the Writers of Yugoslavia, at which M. Krleža gave a speech that is considered as a definite break with the poetics of socialist realism. S. Lasić, Sukob na književnoj ljevici 1928-1952, Zagreb 1970.

${ }^{4}$ Miroslav Krleža, Croatian writer and lexicographer (Zagreb, 1893 - Zagreb, 1981). The central figure of Croatian cultural and social life of the $20^{\text {th }}$ century and the author of a large, multi-genre literary corpus whose masterpieces made him part of the history of Central European literature of the $20^{\text {th }}$ century. Included in many anthologies, and systematically translated to the Hungarian, German and French language.

${ }^{5}$ Krsto Hegedušić, Croatian painter (Petrinja, 1901 - Zagreb, 1975). During the interwar period, one of the founders of the Association of Artists Zemlja (1929-35), an artistic group with a socially engaged programme, which created a specific visual arts expression close to the poetics of the Neue Sachlichkeit movement, and which encouraged the creativity of self-taught peasant painters. After WWII, as a full-time professor at the Academy 
nationally marked Association of Artist Zemlja. ${ }^{6}$ Krleža's foreword unequivocally placed the programmatic orientation of the Zemlja artists on the side that explicitly rejected the normative poetics and trivial instrumentalisation of art of the hard "Kharkov" line, advocating a liberal understanding of socially engaged art, which respects the notional autonomy of artistic expression and modernist stylistic leanings. ${ }^{7}$ Right after the end of the War, the achievements of the Association of Artists Zemlja were still perceived as exemplary for a young socialist society, and so in 1945 Gamulin wrote that their activities "made our visual arts ready to enter the National Liberation Struggle, with open possibilities and a number of developed talents." ${ }^{8}$ The circumstances under which Gamulin modified his opinions on the artistic value of this, but also other segments of pre-war modernist art, are still open for research and interpretation. However, the fact remains that, only a year later, the stylistic idiom of the Zemlja group would be characterised as "left formalism," which runs counter to the tendencies of "realist art. ${ }^{\text {" }}$ By once again confirming such valorisation in a 1949 exhibition review, Gamulin would initiate a harmful and destructive conflict that would go beyond the level of personal disagreement between Hegedušić and himself, and hinder the resolution of tensions on the relation between socialism - modernism, or rather social engagement - aesthetic autonomy till the mid-1950s. It should be emphasised that Gamulin did not consider the antagonism between the art of modernism and the ideology of socialism, which in Yugoslavia also concurred with the radicalisation of social realist doctrine during the so-called "Zhdanov period,"10 to be an $a$ priori, general givenness. In his dialectic consideration of the historical development of art, modernism had its logical place along with other style periods, and as such could not be easily denied or simplistically rejected on an ideological basis. By interpreting the historical and artistic development as a Hegelian advancement of an autonomous form of human understanding or,

of Fine Art in Zagreb and a full member of the Yugoslav Academy of Sciences and Arts, he had a profound influence on the artistic and cultural life, adamantly opposing the doctrine of social realism.

${ }^{6}$ Full name ot the association in Croatian: Udruženje umjetnika Zemlja [zemlja soil, land].

7 P. Prelog, Hrvatska moderna umjetnost i nacionalni identitet, Zagreb 2018, pp. 274-286.

8 G. Gamulin, "Povodom izložbe slikara partizana," Republika 1945, 1(1-2), pp. 106-113.

9 G. Gamulin, „Uz izložbu udruženja likovnih umjetnika Hrvatske“, Naprijed 1946, $4(52)$, p. 3.

${ }^{10}$ Lj. Kolešnik, Između Istoka i Zapada..., Zagreb 2006, p. 29. 
to use Lenin's lexicon, social apprehension of the world, in whose purposeful movement the socialist model of realism represented the next, presumably even the more perfect developmental stage of "coordination" of subjective consciousness and objectivity, ${ }_{11}^{11}$ Gamulin did not deny the possibility that certain attainments of modernist art, as well as those of earlier art-historical periods, could be assimilated into a new socialist norm that appeared historically as a moment of their synthesis. In articles written between 1949 and 1954, Gamulin thus combed with scholarly meticulousness through individual modernist phenomena such as impressionism, Cézanne's style, cubism, etc., and offered a lucid, informed analysis of their stylistic-ontological concepts, which he then rejected as potential role models on a gnoseological basis, due to their ostensibly deficient relationship to human reality, or rather as a resolved stage in the overall social development of art. By the end of 1950s, Gamulin gradually relaxed the relationship between this imaginary socialist realism, which did not follow the Soviet model but appeared as a synthesis of the entire historical development of art, and modernism. For some time after, the Yugoslav cultural scene definitely opened up to artistic developments in Western Europe, but after the appearance of the first abstract expressions in the country, Gamulin continued to represent the position that tried to differentiate the realist orientation in art within the totality of contemporary artistic production, that is, as an orientation which acquired its relative value only in the context of modernism as a whole. By advocating for a selective approach to new artistic tendencies, and criticising an uncritical adoption of stylistic idioms, especially of abstract language in visual arts, Gamulin initiated discussions that actually did not differ from contemporary discussions on left-wing art scene in western democracies. In his texts from the middle of the decade, the problem of the adequacy of socialism and modernism was thus gradually replaced by a polemic on abstract and figurative art. The concept of socialist realism as a separate stylistic-ontological norm, and an innovative one to boot, forever disappeared from his deliberations on the historical and future development of art, whereby the horizon of modernism became the only one within which he would articulate all his subsequent doubts and convictions.

${ }^{11}$ G. Gamulin, „Opća teorija umjetnosti kao teorija socijalističkog realizma“, Zbornik radova Filozofskog fakulteta, Zagreb 1951, 1(1), pp. 155-185, passim. The text represents Gamulin's criticism of the dogmatic concept of social realism espoused by Soviet aesthetics T. Pavlov, M. Rozental, B. Mejlah and others. 


\section{TOWARDS A THEORY OF NAÏVE ART ${ }^{12}$}

Gamulin began writing about naïve art at the very beginning of 1960s. At that point in time, naïve art was on the upswing in Croatia and Yugoslavia: with the establishment of the Gallery of Primitive Art in Zagreb (1952) ${ }^{13}$ and frequent individual and group exhibitions of naïve artists in the country and abroad, naïve artistic production would not only become a successful cultural product on the international scale in mid-1950s and 1960s, but would assert itself as a consistent artistic phenomenon that demanded its explicative support. Besides art critics and gallery managers who promoted and followed this type of art, Grgo Gamulin was the first art historian who systematically theorised this phenomenon; the period between 1961 and mid-1970s saw the emergence of not only one of the most ambitious theories of naïve creation in general, but also of a number of other texts that undoubtedly represent a key contribution to the understanding of the phenomenon of naïve art in the historical context of post-war modernism, to which it largely belongs.

Here the general notice on the notion and term "naïve art" and its historical usage should be made. Although "naiveté" or "primitiveness" was employed as an aesthetic concept in the various art-historical contexts, the notion of "naïve art" addresses particular phenomenon within the modern art of the $20^{\text {th }}$ century. ${ }^{14}$ This kind of art-production was recognized and institutionally affirmed already in the interwar period though under different labels (modern primitives or neo-primitives, the Sacred Heart painters [Les peintures de Sacrè Coeur, W. Uhde], painters of instinct [La peinture d'instinct, R. Huyghe], etc.)..$^{15}$ The "naïve art" as a specific denomination was generally accepted in the period after the Second World War, precisely in the 1950s and

12 The title of Gamulin's first major study on naïve art: "Prema teoriji naivne umjetnosti," Kolo 1965, 3(5), pp. 525-553.

13 Croatian Peasant Educational Society "Peasant Unity" [Seljačka sloga], at the initiative of Franjo Gaži, in 1952 made the decision to initiate a "Permanent Exhibition of Peasant Painters." In 1956, the "Peasant Art Gallery" changed its name to the "Gallery of Primitive Art," and in 1994 became the current Museum of Naïve Art.

14 V. Crnković, "Naiva ili naivna umjetnosti," in: idem, Marginalije ili razotkrivanje nevidljivog, Zagreb 2009, pp. 11-16; N. Vrkljan-Križić, "Naivna likovna umjetnost - autentični stvaralački čin umjetnosti dvadesetog stoljeća" ["Naive visual art in Yugoslavia and in the world - an authentic creative act of $20^{\text {th }}$ century art" $]$, in: Naivna umjetnost / Naive Art, ed. M. Susovski, Zagreb 1991, p. 42.

15 B. Kelemen, Naivno slikarstvo Jugoslavije, Zagreb 1969, pp. 8-10; O. Bihalji-Merin, Naivni umjetnici svijeta, Zagreb 1972, p. 8; V. Crnković, "'Slikari svetog srca' i evropski modernizmi", in: idem, Studije i eseji, recenzije i zapisi, interpretacije. Prilozi za teoriju i povijest naive i art-brutističkih tendencija 1983-1997, Zagreb 2002, pp. 217-224. 
1960s, when the first all-encompassing studies were written by prominent authors such as Anatole Jakovsky and Oto Bihalji-Merin. ${ }^{16}$ It was exactly in this period that naïve art reached the peak of its popularity. Discursively elaborated and widely exhibited, ${ }^{17}$ it was made into ideologically highly invested occurrence, on the basis of which the flexibility of modernist paradigm on both sides of the Iron curtain could be tested..$^{18}$ Gamulin's writings speak of this historical moment.

What had led Gamulin to devote himself so intensively to this issue? As Vladimir Crnković writes, one of the reasons was doubtlessly Gamulin's "faith in figurative painting." ${ }^{19}$ In the artistic milieu of Croatia and Yugoslavia, which had been rapidly liberalising since the early 1950s and opening itself up to the affirmation of various artistic values, including different concepts of abstract visual arts expressions from the geometric to lyrical abstraction and Art Informel, which elicited heated discussions, naïve art also emerged as a radical novelty in the domain of figuration. As an admittedly not avant-garde, but definitely anti-academic occurrence, naïve art offered some sort of compensation to the type of modernist sensibility that was mistrustful of abstract art. Although naïve art did not arise solely as a reaction to the abstract or any other modernist idiom, it still indisputably functioned as an ostensible transgression of the paradigm within the cultural field. It was precisely as a phenomenon that seemingly disrupted the laws of the historically necessitated advancement of art that naïve creative endeavours touched Gamulin's theoretical nerve, which is the second important reason for his interest in the phenomenon. In order to find a plausible foundation for the naïve within the modern epistemology of art, Gamulin developed a number of theories, some of which are still relevant today, as will be shown later on.

${ }^{16}$ Cf. A. Jakovsky, Die naive Malerei in Frankreich, Zürich 1957; idem, Peintres naïfs. Lexikon der Laienmaler aus aller Welt, Hamburg, Wien 1967; O. Bihalji-Merin, Das naive Bild der Welt, Köln 1959 [Croatian ed.: Naivni umjetnici svijeta, Zagreb 1972]; idem, Umetnost naivnih u Jugoslaviji, Beograd 1963 [1959].

17 B. Kelemen, Naivno slikarstvo Jugoslavije, Zagreb 1969, pp. 10-14; V. Crnković, "Naiva u Hrvatskoj pedesetih godina," in: idem, Studije i eseji, recenzije i zapisi, interpretacije. Prilozi za teoriju i povijest naive i art-brutističkih tendencija 1997-2001, Zagreb 2002, pp. $70-84$.

${ }^{18}$ Cf. T. Zimmermann, "Oto Bihalji-Merin and the Concept of the 'Naïve' in the 1950s. Bridging Socialist Realism and Non-Figurative Art," Acta historiae artis Slovenica 2018, 23(1), pp. 185-198.

19 V. Crnković, "Marginalije uz Gamulinove tekstove o 'naivnoj umjetnosti'“, in: idem, Studije i eseji, recenzije i zapisi, interpretacije. Prilozi za teoriju i povijest naive i art-brutističkih tendencija 1997-2001, Zagreb 2002, p. 92. 
The third reason for theorising about naïve art, according to Crnković, ${ }^{20}$ was Gamulin's involvement in the so-called "Bosilj affair"21 which, in addition to being the immediate cause, reflected the notional split of opinions on the genesis of this type of art, which further spurred Gamulin to arm himself with arguments in the face of its opponents.

In addition to representing a rare speculative achievement in Croatian art history, Gamulin's theory of naïve art, set forth in multiple studies and a large number of texts and criticisms in the form of monographs, ${ }^{22}$ also clearly reflects the flexibility and inclusivity of a high-modernist paradigm in a specific historical time and place. It bears witness to an undertaking to incorporate an artistic phenomenon, whose historical continuity in Europe can be traced since the end of the $19^{\text {th }}$ century, and in Croatia since the interwar period, into the dominant artistic discourse and canonise it as a consensual value, while trying to overcome a number of notional and interest antagonisms that had defined the cultural-artistic scene and the framing of the discussion on modernist art in Croatia and Yugoslavia in general for a long time. For the pur-

${ }^{20}$ Ibidem.

${ }^{21}$ The "Bosilj affair" represents the culmination of attempts to discredit naïve creativity as a false, counterfeit phenomenon orchestrated by dishonourable interests. Krsto Hegedušić' publicly raised suspicion about the authorship of paintings by Ilija Bosilj, a farmer from Srijem and the father of art historian and critic D. Bašićević, following public correspondence in which Gamulin and other like-minded individuals rose to his defence, led to a devastating incident when the artist was called by the city government to paint in front of the appointed commission made up of distinguished art historians, artists and other cultural workers (1965).

${ }^{22}$ Gamulin's bibliography numbered over fifty units. In addition to numerous reviews of exhibitions of naïve artists and multiple monographic texts, he also wrote the following theoretic treatises: "Prema teoriji naivne umjetnosti," pp. 525-553 ("K teórii naivné houmenia," Ars 1968, 1; "Toward a Theory of Primitive Art," in: Primitive Painting, Zagreb 1981; New Yok 1981); „U ovom teoretskom trenutku“, Život umjetnosti 1970, 11-12, pp. 3-24; „Plaidoyer za Hlebine.“ Deset teza za simpozij Naivi '73, in: G. Gamulin, Prema teoriji naivne umjetnosti. Studije, eseiji, kritike, prikazi, poelmike 1961-1990, Zagreb 1999, pp. 219-224; I Pittori Naifs della Scuola di Hlebine, Milano 1974; "Contributo critico sul caso di Ligabue naïf," L'Arte Naive 1975, 2(8), pp. 59-62; "Esampi di romanticizmo nella pittura naïve," L'Arte Naive 1975, 2(8), pp. 63-78; Les peintres naïfs. Ecole de Hlebine, Paris 1979; Jugoschlawische Hinterglassmalerei. Ivan Generalić und die Schule von Hlebine, Gütersloh 1982; "Teze o situaciji. Izvještaj za XII. Majsko drugovanje na Sani 1986," in: G. Gamulin, Prema teoriji naivne umjetnosti, Studije, eseiji, kritike, prikazi, poelmike 1961-1990, Zagreb 1999, pp. 289-298; "Naivna umjetnost," in: G. Gamulin, Hrvatsko slikarstvo XX. stoljeća, vol. 1, Zagreb 1987, pp. 504-511. The complete bibliography of Gamulin's texts on naïve art was compiled by V. Crnković in: G. Gamulin, Prema teoriji naivne umjetnosti. Studije, eseji, kritike, prikazi, polemike 1961-1990, Zagreb 1999. 
pose of this text, Gamulin's primary theories on naïve art will be discussed synchronously, not in order of their appearance in Gamulin's studies, but as a collection of ideas that form a relatively rounded theory.

\section{THE AB OVO THEORY:}

\section{VIRGIN DETACHMENT FROM THE HISTORY OF ART}

Since he first started writing about naïve art, Gamulin tried to explain why it should be considered a part of the modern, and for him, contemporary world of art. Without rejecting the possibility that the naïve attitude to artistic expression existed as a general, anthropological modality of creative consciousness, Gamulin explicitly claimed that naïve art was historically constituted as congruent with modernist values - when the "sensitivity of a social milieu" matured to the point where this type of expression was recognised for the values that "already existed as one of the components of modern art." ${ }^{123}$ In other words, naïve art historically did not exist outside the context of modernism, regardless of the character of impulses and the formative context that guaranteed differential qualities, this type of expression could only be actualised as art on the basis of the modernist paradigm. In order to explain the specific affiliation of naïve art to modernism, or rather its genealogy, Gamulin lapsed into a contradiction that was constitutive of the modernist discourse itself; he embraced the so-called theory on its emergence $a b$ ovo which, starting from French interwar art history as well as many distinguished post-war theoreticians of the naïve such as Anatole Jakovsky, ${ }^{24}$ was adopted by many authors who then started to write affirmatively about the naïve - the idea of the absolute originality of the naïve expression that arises from naïve artists' lack of awareness of the historic development of art. On that basis, and already in his first study, Gamulin systemically differentiated the naïve not only in relation to professional, meaning academic art, but also to the folk (popular, folkloric) and lay, or rather amateur art (from which the naïve must be especially distanced). This is unlike the folk artist, whose contribution is based on the preservation of collective traditions without the demand for the originality of expression, unlike the lay artist or an amateur, whose relationship to the art's historical development is structurally epigonic, and unlike the academic artist, whose individual original contribution necessarily implies the experience of the past historic course of art as a whole, the naïve artist "lives and works

${ }^{23}$ Gamulin, "Prema teoriji navine umjetnosti," p. 531.

${ }^{24}$ Cf. A. Jakovsky, La peinture naïve du Douanier Rousseau à nos jours, Bruxelles 1958. 
in virgin detachment from the history of art, and thus, by his very existence, achieves that spontaneity and originality to which a modern artist aspires, usually in vain, and often through artificial means." ${ }^{25}$ In order to explain this isolation of the naïve artist from the historical experience of art and culture in general, Gamulin used the sociological formula of the "blockade" - a low level of artistic and broader cultural awareness and knowledge, arising from different formative circumstances, keep the naïve artist permanently but effectively in cognitive isolation, basically imprisoned in positions that guarantee authenticity and originality of his artistic impulse, so that even potential influences from the current artistic milieu are "assimilated by the naïve core," without dislodging it "from its naïve relationship to the world." ${ }^{26}$ Gamulin's high esteem of originality was, therefore, a typically modernist position; precisely at the moment when the distinctiveness or declination from academic norms was recognised as the value of originality, naïve art became part of the historic course of art, building on it with its specific contribution. In addition to an understandable determinedness by the discourse of the time, Gamulin's insistence on the $a b$ ovo theory, or rather on the postulate of the zero level of artistic experience and the absolute unconditionality of expression of a naïve artists, also reflected current divisions related to the issue of the genesis and worth of naïve art among Croatian critics and artists, as well as split opinions on the understanding of modernism in general. Gamulin's aspiration to defend the absolute authenticity of the naïve expression is a reflection of the already mentioned restraint towards the issue of external, extrinsic artistic influence in general, or rather the fundamental conviction about the necessity of an ontological foundation of art in the immediate, subjective experience of reality and the cultural experience of the social environment. In particular, behind the theory of the intactness of naïve artistic expression stands the current division of attitudes on the genesis of this art in the Croatian context. Unlike the proponents of the naïve artistic expression, part of the elite led by Miroslav Krleža did not accept the theory on the authenticity of this phenomenon, considering it an induced, even interest-motivated construct. An argument for such a judgement was within easy reach, in the historical fact of the role that Krsto Hegedušić played in stimulating peasant painting in the interwar period, and in the context of socially engaged programme of the Association of Artists Zemlja, in which that painting had such a clear ideological mission. In relation to that historic moment, the new flourishing of the naïve was judged by its detractors as an aberration of once-progressive

\footnotetext{
25 Gamulin, "Prema teoriji navine umjetnosti," p. 544 [italic- G. G.]

${ }^{26}$ Ibidem, p. 546 [italic-G. G.]
} 
positions. From today's perspective, the verdict is easy to reach: just like other artistic phenomena, naïve art also rested on active communication between competing artistic concepts and organised institutional support, which does not detract from the uniqueness of particular artistic oeuvres nor from artistic credibility of the phenomenon as such. Nevertheless, within the paradigm in which it was precisely the category of individual artistic genius that represented one of the basic categories that could secure competitive status for naïve artists on the market of artistic ideas, individuals were taking up firm, radical positions, and Gamulin was no different. Although he did not abandon the basic idea of the substantially asymmetrical relation of naïve consciousness and historical development of art, over time Gamulin would nonetheless partly relativize his rigid attitudes on the possibility of extrinsic influences, as will be demonstrated.

\section{THE NAÏVE CORE OF STYLE}

The second problem that Gamulin had to tackle in his theorising is the formation of style in naïve artists; namely, how does a naïve artist, whose "historical experience is completely cut off, and the personal one unfolds within a narrow register determined by the character of the blockade," manifests precisely that "characteristic which is common to modern art" - "the absolute singularity of style" 27 - a crucial quality that distinguishes him from the artist-amateur? Raising this issue, Gamulin again explicitly asked how naïve art had achieved its qualitative stylistic distinction while existing outside the historical horizon of art. In answering this question, he immediately rejected the reasoning advocated by some theoreticians, namely that it is a matter of naïve realism, meaning mere description. ${ }^{28}$ Gamulin again offered a solution in line with his pronouncedly modernist understanding of a work of art, which still ran along the line of theories formulated by Jakovsky and La Motte. ${ }^{29}$ Understandably, we cannot talk about realism in connection with naïve artists, because realism is also a stylistic concept determined by historical development; with naïve artists, on the contrary, it is a question of constitutive failure of imitation, or rather a failure in depicting the world:

27 Ibidem, pp. 540-541 [italic - G. G.].

${ }^{28}$ In this context, Gamulin singles out Jean Cassou and Werner Haftman.

29 Gamulin quotes A. Jakovsky and M. de la Motte: A. Jakovsky, "Cespeintres de la semaine des sept dimanches," in: Les peintres naïfs, Knokke-le-Zoute 1958 [exhibition catalogue]; M. de la Motte, "Naive Kunst?" in: Das naive Bild der Welt, Baden-Baden 1961 [exhibition catalogue]. 
in an attempt to portray the world, naïve artists instinctively impose their own symbolical system, or rather their sign language, on the referent reality, achieving an autonomy in relation to all aesthetic norms, including the realistic one, to which a modern artist can only aspire. "He paints as he exists, in unity with his expression, but without a conscious (historical) relation to that expression." ${ }^{30}$ A naïve artist's style is therefore a given of his limited gnoseological disposition, and not stylistic self-possession that can develop only as a historically-relative value. Defending his basic postulate on the extrahistoricity of naïve artistic concept, Gamulin would, however, find himself faced with several additional problems. First of all, how does the individualisation of expression, as the basic assumption of art in the modern sense, even take place within such absolute symbolisation? Secondly, how can one explain the stylistic development of certain individual oeuvres which last in time? And finally, how to explain the phenomenon of a school as stylistic interconnectedness within a group of naïve artists? Gamulin solved the problem of the individualisation of expression with the already mentioned theory of the blockade - sociologically-conditioned isolation of a naïve artistic subject from the institutional world of art. Namely, the circumstances of the blockade differ from one artist to another, which leads to differences in the imagination - it is thus not a matter of conscious aspiration towards the individualisation of expression in relation to the totality of artistic possibilities, but of a necessary determinateness of contingent circumstances of existential isolation. In line with such deliberations, Gamulin initially also espoused a theory of the "immobility"31 of the once-attained expression, which he eventually abandoned when faced with changes in style and subject matter in artists whose work he continuously followed. ${ }^{32}$ Naturally, he interpreted the dynamic in the expression within individual oeuvres as a subjectively inherent process; although naïve artists develop an indisputable "painterly consciousness," meaning a meta-linguistic relationship towards their own system of forms, their stylistic development is immune to the movements of the art world - "tangential impulses and interventions" that may come from it would be completely as-

${ }^{30}$ Gamulin, "Prema teoriji navine umjetnosti," p. 541.

31 "The phenomenon which had, namely, been detected early on in connection to naïve art is the immobility of their painterly (or sculptorly) vision." Ibidem, p. 545.

32 "Perhaps the concept of its general immobility will soon have to be revised, but its dynamics is not in the genesis of contemporary expressions.” G. Gamulin, „U ovom teoretskom trenutku," Život umjetnosti 1970, 11-12, p. 24. Cf. also: V. Crnković, "Marginalije uz Gamulinove tekstove o 'naivnoj umjetnosti,'”' p. 93, 96. 
similated by the "naïve core," 33 which is the underlying basis for the stylistic genesis of naïve artists.

The problem of the school as a consistent style formation is something that Gamulin would consistently tackle and, in considering the topic, eventually go furthest in correcting his own starting point. At the very beginning of his speculation, he explicitly raised the question of the famous Hlebine ${ }^{34}$ or any other school: "Is that not a 'contradiction in the substantive'? For, if naïve expression is, by its definition, isolated and individual, how is it possible for the phenomenon of a 'school' to appear, or any other stylistic connection between naïve artists?" 35 The answer he first offered was again based on the concept of the blockade, which applied equally well to the level of the collective: without denying the factuality of mutual influences of artists who live and work together, Gamulin claimed that it was a coherent style occurrence that arose from the closedness of the environment. The point at issue was the "multiplication of focal points within a homogeneous cultural and psychological environment, without external interventions," which over time even led to the "emergence of solidarity of an artistic region" and a deliberate "defence of style." ${ }^{36}$ In this context, Gamulin also debated with critical positions which held that with the emergence of a "school," art stopped being naïve and transformed into a manner that was open to the siren call of the world of art and the market. ${ }^{37}$ Gamulin would return to the problem of the formation and development of a school as a unique style formation in a comprehensive monographic text on the Hlebine School, in which he systematically elabo-

${ }^{33}$ G. Gamulin, "Prema teoriji navine umjetnosti," p. 546. G. refers to O. Bihalji, who writes about the visibility of different influences in the oeuvres of individual naïve artist, but who remained undeclared regarding the ab ovo theory. O. Bihalji-Merin, Das naive Bild der Welt, Köln 1959 (Croatian edition: Naivni umjetnici svijeta, Zagreb 1972).

${ }^{34}$ Hlebine School. The name that is used for several generations of painters from Podravina, a region in northern Croatia. The name comes from the village of Hlebine, home to the two painters from the first generation (Ivan Generalić, Franjo Mraz), who were encouraged to paint by the academic painter K. Hegedušić in the first half of the 1930s. As the Ecole de Hlebine, it was first mentioned in 1955 at the Biennale in São Paolo, where it was first introduced to the international public. The H. School includes the following: in the first generation Ivan Generalić, Franjo Mraz and Mirko Virius; in the second generation Franjo Filipović, Dragan Gaži, Josip Generalić, Ivan Večenaj, Mijo Kovačić, Martin Mehkek, Ivan Lacković; several artists of the third generation appeared during the 1970 s.

35 Gamulin, "Prema teoriji navine umjetnosti," p. 552 [italic - G. G.].

${ }^{36}$ G. Gamulin, "Pledoayer za Hlebine," in: idem, Prema teoriji naivne umjetnosti. Studije, eseiji, kritike, prikazi, poelmike 1961-1990, Zagreb 1999, p. 231, 233.

${ }_{37}$ Gamulin primarily debates with painters Albert Dasnoy and Klaus Jürgen-Fischer, but also with Oto Bihalji. 
rated on the problem. ${ }^{38}$ First of all, Gamulin emphasised the criteria necessary for talking about a "school": first, that a recognisable style idiom functioned in a more or less confined area as a precondition for interaction and influences; second, that a style idiom lasts in time, transferring a relatively consistent linguistic, or rather morphological system from generation to generation; and, third, that there was a formation of a "milieu of spiritual atmosphere," meaning a specific cultural environment. "Fundamental attribute is, therefore, the emergence and functioning of style, of the especially created expression, which was suggestive enough to activate the imagination and creative energies of other potential self-taught artists in its surroundings, and whose activities were durable enough to enable the suggestive radiation of a firmly-formed expression to become prominent." ${ }^{\prime 39}$ Undoubtedly, the formation and existence of the school was primarily interpreted by Gamulin in an autogenetic manner: as a logical consequence of the effect of strong creative personalities - in the case of the Hlebine School it was Ivan Generalicí ${ }^{40}$ - whose work, through the "radiation of style," encouraged talented individuals to create their own expression. In this context, Gamulin also cast a careful, historiographic eye on the influence of left-leaning Association of Artists Zemlja and Krsto Hegedušić on the formation of the school in the interwar period; he did not contest their contribution to the affirmation of naïve artists, but strongly defended the thesis on the fundamental disconnectedness of cultural spheres that were brought into conjunction only by the ideological context, and not by the world of art they shared. In this sense, stylistic interaction cannot be fruitful either - influences that come from the academic sphere can result only in a malaligned coalescence, and not creative assimilation. "By its

38 Gamulin, "Naivni slikari Hlebinske škole." The text was also published in the Italian (1974), French (1979) and German edition (1982), while the original Croatian text is only now being readied for publication. I thank V. Crnkovic for the access to the manuscript.

39 Gamulin, "Naivni slikari Hlebinske škole" [manuscript], p. 10 [italic- G. G.].

${ }^{40}$ Ivan Generalić (Hlebine, 1914 - Koprivnica, 1992), naïve painter. The central figure of the Hlebine School. In the interwar period, his w Naivni slikari Hlebinske škole ork was encouraged by the painter K. Hegedušić, one of the founders of the artistic association Zemlja, with which he had his first exhibition (1931-1935). While the period until WWII was thematically related to social problems of the village, after the War he developed a specific bucolic imagery, which from late 1950s also included surreal, magic realistic elements, and during the 1970s he made a turn towards existentialist, allegoric content. He had a number of solo exhibitions in the country and abroad (Paris 1953, Brussels 1959, Munich 1965, Solothurn and Düsseldorf 1966, Zürich 1967, Basel 1968, Florence and Geneva 1971, Offenbach 1972, Köln 1976) and participated in numerous group exhibitions of Croatian and other naïve art. His paintings hang in Croatian and foreign museums and collections (France, Germany, Switzerland etc.). 
cultural sense, its emergence and, ultimately, its spiritual range as well, these are two different phenomena that can arise in different strata of cultural existence. Mutual interferences can have the function of a catalyst, but cannot be decisive for the creative range. They were not decisive in this case." ${ }^{\prime 1}$

\section{THE FUNCTION OF THE “LOST CHILDHOOD”}

The third line of Gamulin's investigation of naïve art appertains to a wider social and cultural sense of this phenomenon. Namely, if naïve art emerges on the historical stage as an event of radical artistic discontinuity, and as such plays a direct part in contemporaneity, or rather the culture of modernity, it must be determined what its significance is in this context and which values form the basis for its communication with its contemporaneity. Gamulin's answer is the following: naïve art has the value of compensation. In the culture of modernity which, not even in the socialist version, can avert the sense of alienation on the relation between the individual - collective, in which civilizational weariness stirs a yearning for simple forms of existence, and art follows its autonomous path of development that leaves "unsatisfied the bright aspirations and needs," ${ }^{42}$ naïve art necessarily populates the emptied places. "Into those empty spaces - from its hidden shelters, from the edges of today - came naïve art, discovering the unmet needs of simple people, and even jaded ones, the tired criticism and confused theory, and that is why it was accepted." ${ }^{43}$ Gamulin was not alone in this interpretation of the naïve as a therapeutic supplement; other distinguished writers involved with naïve art, especially Mića Bašićević, ${ }^{44}$ were pushing for just such an interpretation, arguing that naïve art opened up the artistic experience to the pre-modern, primordial, primal experiences. "Was it a desire of our times for the lost naiveté of art ..., and a desperate, hopeless hope that we can recover our lost childhood?,"

${ }^{41}$ Ibidem, p. 12.

${ }^{42}$ G. Gamulin, "U ovom teoretskom trenutku," Život umjetnosti 1970, 11-12, p. 19.

43 Ibidem.

${ }^{44}$ Dimitrije (Mića) Bašićević - Mangelos, art historian and conceptual artist (Šid, 1921 - Zagreb, 1987). Co-founder of the Gallery of Primitive Art in Zagreb, which he headed between 1960 and 1965. With the exhibitions he organised and the reviews and introductions he wrote, Bašićević made a critical contribution to the conceptualisation and evaluation of naïve art, as well as to its affirmation in Yugoslavia and abroad. His texts on naïve art were collected in: Mića Bašićević, Studije i eseji, kritike i zapisi, 1952-1954, ed. V. Crnković, Zagreb 1995; Mića Bašićević, Studije i eseji, kritike i zapisi, 1955-1963, ed. V. Crnković, Zagreb 1995. 
asked Gamulin rhetorically. ${ }^{45}$ To be sure, the question implicitly contained the answer: "naïve art" was an ideal that had been lost in advance; the immediacy between the existential experience and artistic consciousness that Gamulin invoked did not even apply to naïve art itself, which was proven by his ramified theory. Naïve creativity therefore tied in with values that have existed within modernism for a long time: the art of modernism and the culture of modernity constitutively fostered a sensibility for everything that could be described with a sign of the pre- or anti-modern, meaning everything that could represent a dialectic antithesis to the dominant cultural paradigm. Still, if one considers the fact that it was precisely during the period of the rise of the naïve that the artistic culture in Croatia and Yugoslavia was marked by the definite adoption of an abstract visual art language in its high-modernist conception, it is understandable that the relation of these, at least seemingly opposed artistic phenomena within the same paradigm, impressed itself on Gamulin and other witnesses of the time as an epistemological problem. It was precisely from the position of a purportedly radical alterity that naïve creativity could become part of the historical course of art and the modernist order; it was exactly as a compensation for an imaginary projection of "childhood" that the naïve defended its values.

\section{CONCLUSION}

Gamulin's theory of naïve art is a monumental example of the modernist understanding and evaluation of art. Wanting to explain and defend the phenomenon of the naïve as a relevant artistic occurrence, Gamulin reached for the fundamental concepts of the modernist paradigm: through the $a b$ ovo thesis - a theory that naïve art does not arise as a conditioned result of the historical development of art, but as a self-grown phenomenon, independent of artistic circumstances and based solely on the intrinsic motivation of a creative subject, who sublimates their own existential situation into a creative expression - he granted naïve art the value of authenticity, or originality; by rejecting the postulate on naïve realism and emphasising the stylistic self-consciousness of a naive creator, or rather an entire school which managed to build a consistent morphological and narrative universe, he ensured the value of autonomy; and by interpreting the social significance of this creative endeavour as a declaration of suppressed, inhibited moods and aspira-

\footnotetext{
${ }^{45}$ Gamulin, "Prema teoriji navine umjetnosti," p. 528.
} 
tions, he ensured the value of otherness, or alterity, as the third value that is constitutive of the culture of modernity. ${ }^{46}$

Even though our contemporary perception of naïve art differs from Gamulin's theoretic interpretation, it represents an unambiguous affirmation of the historical and stylistic affiliation of this occurrence with the order of high-modernism, which established itself in 1950s Yugoslavia as an aesthetic and ideological norm of artistic production that Gamulin, after abandoning the horizon of socialist realism, basically endorsed. With the benefit of historical hindsight, today we understand this phenomenon as an occurrence that started, functioned and came to an end within one era; the intertextual permeation of naïve art with stylistic patterns and artistic concepts that it perforce shared with the academic artistic sphere, does not lessen the appraisal of creativity of individual contributions, which makes the problem of its genesis and position within the art world not substantially different from any other modernist occurrence. However, Gamulin and his contemporaries like Bašićević, as informed witnesses of the cultural "opening-up," or the adoption of contemporary artistic tendencies, reached for the here-expounded type of argumentation in order to legitimise this phenomenon as a competitive contribution, opportunely recognising an artistic concept through which Yugoslavia played a relevant role in the international culture of modernism.

\section{BIBLIOGRAPHY}

Bihalji-Merin O., Naivni umjetnici svijeta. Povijesni pregled, suvremena kretanja, perspektive, Zagreb: Mladost 1972 [Das naive Bild der Welt, Köln 1959]

Bihalji-Merin O., Umetnost naivnih u Jugoslaviji, Beograd 1963

Crnković V., "Marginalije uz Gamulinove tekstove o ,naivnoj umjetnosti'," in: idem, Studije i eseji, recenzije i zapisi, interpretacije. Prilozi za teoriju i povijest naive i art-brutističkih tendencija 1997-2001, Zagreb 2002, pp. 89-124

46 The triad of authenticity - autonomy - alterity was taken from Cornelia Klinger: C. Klinger, "Autonomy - Authenticity - Alterity: On the Aesthetic Ideology of Modernity," in: Modernologies. Contemporary Artists Researching Modernity and Modernism, ed. S. Breitwieser, Barcelona 2009 [exhibition catalogue], pp. 25-37.

Reflection of these values in the critical discourse on naïve art in 1960s Croatia, see: I. Mance, "Rastezljivost paradigme: 'naivno' prema 'modernom' u diskursu hrvatske povijesti umjetnosti i likovne kritike šezdesetih godina," in: Ivan Generalić. Dielo, život, vrijeme. Zborni kradova znanstveno-stručnog simpozija povodm 100. Obljetnice rodenja Ivana Generalića, Koprivnica 2016, pp. 11-18. 
Crnković V., "Naiva u Hrvatskoj pedesetih godina," in: idem, Studije i eseji, recenzije i zapisi, interpretacije. Prilozi za teoriju i povijest naive i art-brutističkih tendencija 1997-2001, Zagreb 2002, pp. 70-84

Crnković V., ",Slikari svetog srca' i evropski modernizmi," in: idem, Studije i eseji, recenzije i zapisi, interpretacije. Prilozi za teoriju i povijest naive i art-brutističkih tendencija 1983-1997, Zagreb 2002, pp. 217-224

Crnković V., "Naiva ili naivna umjetnosti," in: idem, Marginalije ili razotkrivanje nevidljivog, Zagreb 2009, pp. 11-16

Gamulin G., "Povodom izložbe slikara partizana," Republika 1945, 1(1-2), pp. 106113

Gamulin G., "Uz izložbu udruženja likovnih umjetnika Hrvatske," Naprijed 1946, $4(52)$, p. 3

Gamulin G., "Opća teorija umjetnosti kao teorija socijalističkog realizma," Zbornik radova Filozofskog fakulteta, Zagreb 1951, 1(1), pp. 155-185

Gamulin G., "Prema teoriji naivne umjetnosti," Kolo 1965, 3(5), pp. 525-553 [also in: G. Gamulin, Prema teoriji naivne umjetnosti. Studije, eseji, kritike, prikazi, polemike 1961-1990, ed. V. Crnković, Zagreb 1999, pp. 73-128; other editions: "K teórii naivné houmenia," Ars 1968, 1; "Toward a Theory of Primitive Art," in: Primitive Painting, Zagreb 1981; New Yok 1981]

Gamulin G., „U ovom teoretskom trenutku,” Život umjetnosti 1970, 11-12, pp. 3-24 [also in: G. Gamulin, Prema teoriji naivne umjetnosti. Studije, eseji, kritike, prikazi, polemike 1961-1990, ed. V. Crnković, Zagreb 1999, pp. 155-190]

Gamulin G., "Plaidoyer za Hlebine." Deset teza za simpozij Naivi '73, in: idem, Prema teoriji naivne umjetnosti. Studije, eseji, kritike, prikazi, polemike 1961-1990, ed. V. Crnković, Zagreb 1999, pp. 219-224

Gamulin G., Naivni slikari Hlebinske škole, manuscript [recently published as: G. Gamulin, Naivni slikari Helbinske škole, ed. V. Crnković, Zagreb 2019; other editions: I Pittori Naifs della Scuola di Hlebine, Milano 1974; Les peintres naïfs. Ecole de Hlebine, Paris 1979; Jugoschlawische Hinterglassmalerei. Ivan Generalić und die Schule von Hlebine, Gütersloh 1982]

Jakovsky A., Die naive Malerei in Frankreich, Zürich 1957

Kelemen B., Naivno slikarstvo Jugoslavije, Zagreb 1969

Klinger C., „Autonomy - Authenticity - Alterity: On the Aesthetic Ideology of Modernity," in: Modernologies. Contemporary Artists Researching Modernity and Modernism, ed. S. Breitwieser, Barcelona 2009 [exhibition catalogue], pp. 25-37

Kolešnik Lj., Izmedu Istoka i Zapada. Hrvatska umjetnost i likovna kritika 50-ih godina, Zagreb 2006

Lasić S., Sukob na književnoj ljevici 1928-1952, Zagreb 1970

Mance I., "Rastezljivost paradigme: ,naivno' prema ,modernom' u diskursu hrvatske povijesti umjetnosti i likovne kritike šezdesetih godina," in: Ivan Generalić. Djelo, život, vrijeme. Zborni kradova znanstveno-stručnog simpozija povodm 100. Obljetnice rođenja Ivana Generalića, Koprivnica 2016, pp. 11-18

Prelog P., Hrvatska moderna umjetnost i nacionalni identitet, Zagreb 2018

Šeparović A., „U znaku totalitarizma,” in: 150 godina Hrvatskog društva likovnih umjetnika. Umjetnost i institucija, ed. I. Kraševac, Zagreb 2018, pp. 173-200 
Vrkljan-Križić N., „Naivna likovna umjetnost - autentični stvaralački čin umjetnosti dvadesetog stoljeća“ [„„Naive visual art in Yugoslavia and in the world - an authentic creative act of 20th century art"], in: Naivna umjetnost / Naive Art, ed. M. Susovski, Zagreb 1991, pp. 7-44 [45-86]

Zimmermann T., "Oto Bihalji-Merin and the Concept of the 'Naïve' in the 1950s. Bridging Socialist Realism and Non-Figurative Art," Acta historiae artis Slovenica 2018, 23(1), pp. 185-198

Ivana Mance

University of Zagreb

TOWARDS THE THEORY OF THE NAÏVE ART GRGO GAMULIN AND THE UNDERSTANDING OF MODERNISM

\section{Summary}

The article presents the theory of naïve art of the Croatian art historian Grgo Gamulin (1910-1997), which he developed in a number of texts written from early 1960s. In his theory, Gamulin tried to explain the phenomenon of naïve art on the basis of the modernist paradigm by applying the type of argumentation that is characteristic for the discourse of high-modernity. Gamulin's postulates on the naïve can be summarised with a few basic lines of speculation. First of all, Gamulin claims that the phenomenon of the naïve was epistemologically possible only in the context of modernism, and that it should therefore be considered an equally valuable movement of contemporary art. However, in order to defend its authenticity, he began adhering to the $a b$ ovo theory, the notion that naïve art does not arise as a cumulative result of the historical development of art, but that it ontologically precedes that development. The naïve artist, according to Gamulin, always starts from the beginning, independent of events in the art world, and immune to influences. A naïve artist is therefore necessarily authentic, or rather original: not having any role models, he develops an individual style, independently building his own visual arts language. Gamulin further posits that the visual arts language of the naïve is not based on a naive imitation of reality, or mimesis, but on an instinctive, spontaneous symbolisation of subjective experience, and as such is completely autonomous in relation to the laws of reality, i.e. it is ontologically grounded in the artist's imagination. Finally, in an effort to explain the social significance of naïve art, Gamulin interprets the emergence of the naïve in the context of the culture of modernism as compensation - a supposedly naïve attitude to aesthetic norms, as well as an imaginarium that evokes "lost spaces of childhood," necessarily functions as a therapeutic substitute for the alienation of art and the modern life in general. As such, Gamulin's theory vividly testifies to the character of naïve art as a phenomenon that is constitutive of the culture of modernism, but that also reflects a number of contemporary polemics and split opinions, not only on the topic of the naïve but of modernism as a whole. The split of opinions on naïve art, especially 
with regard to its genesis, partly reflects the positions of the so-called conflict on the left, discussions that were taking place between the interwar period and early 1950s with the aim of defining the relationship of leftist ideology to modernism, or rather the relationship between the values of socially-critical engagement and aesthetic autonomy. The discussion on the naïve, however, experienced a certain changing of sides - Grgo Gamulin, a one-time advocate for socialist realism, began supporting naïve art and thus rose to the defence of basically liberal understanding of modernism, while former opponents of socialist realism denounced the phenomenon of the naïve as ideologically inconsistent and aesthetically doctored. In conclusion, Gamulin's theory, as well as the entire polemic around naïve art that was taking place during the 1960s and which the theory necessarily ties in with, demonstrates the complex contextual reality of a seemingly integral modernist paradigm, illustrating the confrontation of positions that is by no means peculiar to Yugoslav society.

Keywords:

Grgo Gamulin, Croatia, naïve art, modernism, art theory, art historiography 